\title{
Omsorgstjänster för äldre och funktionshindrade: skilda villkor, skilda trender?
}

\author{
MARTA SZEBEHELY \& GUN-BRITT TRYDEGÅRD
}

Välfärdsstatens insatser för personer med funktionshinder och för äldre människor särskiljs sällan i statistik och forskning. När, somi denna artikel, verksamheterna separeras,

blir det tydligt att de båda välfärdstjänsterna under senare år har utvecklats åt skilda häll. Ekonomiska resurser, tjänsternas omfattning och personalens arbetsvillkor skiljer sigpåtagligt mellan äldre- och handikappomsorgen, och gränsen mellan statens, familjens och marknadens roller har förskjutits på olika sätt.

I internationell välfärdsforskning brukar framhållas att de nordiska välfärdsstaterna kännetecknas av omfattande skattefinansierade omsorgstïnnster av hög kvalitet, huvudsakligen utförda av offentliganställd personal, riktade till och utnyttjade av alla samhällsklasser i livets olika skeden (se t.ex. Sipilä 1997, Daly \& Lewis 2000). Men inte heller i Norden utförs merparten av omsor-

Marta Szebehely, professor vid institutionen för socialt arbete, Stockholms universitet.

Gun-Britt Trydegård, fil. dr och forskare vid institutionen för socialt arbete och CHESS, Stockholms universitet. gen av offentligt anställd personal. En stor del av omsorgen utförs oavlönat inom familjen - ofta av kvinnor - och en ökande andel av det offentligt finansierade omsorgsarbetet utförs av privata företag. Vem som utför det nödvändiga omsorgsarbetet är inte givet, vare sig i ett historiskt eller nationellt komparativt perspektiv - eller i dagens Sverige. Den internationella forskningen på området betonar att omsorgstjänsternas historia alltid har präglats av gränsomdragningar mellan avlönat och oavlönat arbete, och mellan familjen, staten, frivilligsektorn och marknaden som utförare av omsorgs-

Marta Szebehely \& Gun-Britt Trydegård: Omsorgstjänster för äldre och funktionshindrade... 
arbetet (t.ex. Daly 2002, Anttonen et al. 2003, Pfau-Effinger 2005).

Hur mycket av omsorgen som i ett samhälle utförs av de olika aktörerna hänger samman med familje- och socialrättslig lagstiftning. I Norden har familjen inget lagstadgat ansvar när det gäller omsorg om vuxna människor; det yttersta ansvaret vilar på kommunerna. Men för att familjemedlemmar inte ska vara tvungna att ta på sig ett omsorgsansvar måste de offentligt finansierade omsorgstjänsterna vara tillräckligt omfattande och av så pass god kvalitet att de framstår som ett möjligt alternativ. Omsorgstjänsternas resurstilldelning, omfattning, utformning och organisering har därför stor betydelse för många medborgare. Det gäller inte bara de som varaktigt eller tillfälligt behöver andra människors hjälp för att klara sin vardag utan också deras närstående och dessutom de 100000 -tals anställda - främst kvinnor - som har omsorgstjänsterna som sin arbetsmarknad.

I denna artikel ska vi fokusera på två av dessa omsorgstjänster: välfärdstatens insatser för personer med funktionshinder och för äldre människor - två grupper där många är beroende av andra människors hjälp i sin vardag. Artikelns syfte är att belysa hur omsorgstjänster inom de båda verksamhetsområdena har förändrats under de senaste femton åren. Genomgående diskuterar vi konsekvenserna för de närmast berörda - de äldre resp. funktionshindrade, deras närstående och personalen inom verksamheterna. Ansatsen är i huvudsak deskriptiv, och följande frågor belyses:

- Vad har hänt med resursutveckling och omsorgstjänsternas omfattning?
- Skiljer sig personalens arbetsvillkor?

- Vilken roll har offentliga respektive privata utförare inom de offentligt finansierade omsorgstjänsterna?

- Har gränsen mellan familjens, statens och marknadens roller förskjutits?

\section{Omsorg om äldre och funktionshindrade - skilda verksamheter?}

En första fråga som inställer sig är om det över huvud taget är rimligt att tala om två skilda omsorgstjänster för äldre och för funktionshindrade. Skulle man inte lika gärna kunna tala om vuxenomsorg eller funktionshindersomsorg i båda fallen? Detta är delvis en begreppslig fråga - man kan naturligtvis vara både funktionshindrad och äldre, och den som är äldre men inte har några funktionsnedsättningar är knappast aktuell för äldreomsorgens insatser. I policydokument och kommunal verksamhet är dock åldersgränsen 65 år viktig. Ett funktionshinder som är medfött eller förvärvat före 65 års ålder betraktas inte på samma sätt som motsvarande funktionshinder som uppstått senare i livet (se Jönson \& Taghizadeh 2006).

Denna åtskillnad är tydlig i lagstiftningen på området. Alla med omsorgsbehov - oavsett ålder och typ av funktionshinder omfattas av Socialtjänstlagen (SoL), medan personer med omfattande funktionshinder som »uppenbart inte beror på normalt åldrande» under vissa förutsättningar också kan omfattas av Lagen om stöd och service till vissa funktionshindrade (LSS); i vissa fall 
dessutom av Lagen om assistansersättning (LASS); bägge lagarna trädde i kraft 1994 vid den s.k. handikappreformen, då kommunerna fick ett ökat ansvar för stöd till personer med funktionshinder (se Barron et al. 2000, Åström 2000).

Dessa lagar skiljer sig åt till sin utformning. Både SoL och LSS/LASS är visserligen målinriktade rättighetslagar, vilket innebär att den enskilde kan överklaga och få sin sak prövad i förvaltningsdomstol, om beslutet går honom eller henne emot (Åström 2000). Men SoL är en målinriktad ramlag, som utan närmare precisering anger att enskilda har rätt till bistånd om de inte kan få sina behov tillgodosedda på annat sätt. LSS är en "renare rättighetslag" (Åström 2000 s. 257) som anger explicit de personkretsar - grupper av personer med vissa specificerade funktionshinder - som har rätt till insatser om de behöver sådan hjälp. LSS anger också tio olika insatser som den enskilde har rätt till. LSS kan alltså sägas präglas av ett mera centraliserat beslutsfattande (lagstiftaren har bestämt vem som skall få vilka insatser), där kommunerna har ett snävare handlingsutrymme. Också målen för verksamheten uttrycks på olika sätt: enligt LSS skall insatserna tillförsäkra den enskilde "goda levnadsvillkor" medan SoL talar om en "skälig levnadsnivåu. I LSS framhävs också att insatserna ska vara varaktiga och samordnade, anpassade till den enskildes behov och lätt tillgängliga, något som inte nämns i SoL. Till skillnad från SoL betonas i LSS särskilt brukarnas rätt till inflytande och medbestämmande över de insatser som ges.

I en studie av personer med personlig assistans säger en av de intervjuade: "Jag hade tur som fick stroke före 65 « (Forssell 1994 s. 86). Den drastiska formuleringen avspeglar de mer generösa samhällsinsatserna för yngre personer med funktionshinder jämfört med äldre i motsvarande situation. Men som Åström (2000) påpekar går det en skiljelinje också mellan olika grupper funktionshindrade. De personer med funktionshinder som inte ingår i någon personkrets enligt LSS har en avsevärt svagare rättslig ställning; deras lagliga rättigheter skiljer sig inte från personer som blivit funktionshindrade efter 65 års ålder.

I många kommuner samlas verksamheterna under en sammanslagen beteckning: äldre- och handikappomsorg. Andra kommuner skiljer på verksamheterna och talar om äldreomsorg respektive handikappomsorg, eller i det senare fallet om insatser eller stöd och service för personer med funktionshinder. Omsorg är ett begrepp med tvivelaktig klang bland många personer med funktionshinder (se t.ex. Fine \& Glendinning 2005), men i många policysammanhang (t.ex. hos Socialstyrelsen och Sveriges Kommuner och Landsting) används fortfarande begreppet handikappomsorg. Själva använder vi här av praktiska skäl ofta begreppet handikappomsorg, och vill betona att detta inte är ett uttryck för något ställningstagande i denna kontrovers.

\section{Resurser och verksamhet}

Kommittén Välfärdsbokslut redovisade i sin slutrapport (SOU 2001:79) olika utvecklingsmönster för de två omsorgstjänsterna äldreomsorg och handikappomsorg. Medan 1990-talet betecknades som

Marta Szebehely \& Gun-Britt Trydegård: Omsorgstjänster för äldre och funktionshindrade... 
ett relativt offensivt decennium när det gällde stöd för personer med funktionshinder, kännetecknades det för äldreomsorgens del av åtstramning av resurser och en minskning av andelen hjälpmottagare.

På funktionshinderområdet introducerades, mitt under de svåraste krisåren, handikappreformen med den tidigare nämnda lagstiftningen för de svårast funk- tionshindrade (LSS/LASS). Samhällets ekonomiska resurser för stöd och hjälp till personer med funktionshinder ökade (i fasta priser) med 68 procent mellan 1993 och 1999 (a.a. s. 109). Genom den nya lagstiftningen ökade insatserna främst för funktionshindrade med stort behov av hjälp, medan funktionshindrade med mindre hjälpbehov, som inte tillhörde personkret-

\section{Tabell I.}

Resurser till äldre- och handikappomsorg ( $i 2005$ års priser) samt antalet personer med insatser 2000-2005.

\begin{tabular}{|c|c|c|c|}
\hline & 2000 & 2005 & $\begin{array}{l}\text { Procentuell } \\
\text { förändring } \\
2000-2005\end{array}$ \\
\hline Äldreomsorg: resurser miljarder kr & 82,9 & 80,3 & $-3,1$ \\
\hline $\begin{array}{l}\text { Äldreomsorg: antal personer med } \\
\text { insatser, varav ... }\end{array}$ & 239200 & 235400 & $-1,6$ \\
\hline ...hemtjänst & 120900 & 135000 & $+12,0$ \\
\hline ...boende & 118300 & 100400 & $-|5|$, \\
\hline $\begin{array}{l}\text { Handikappomsorg': (inkl statl. LASS), } \\
\text { resurser miljarder kr }\end{array}$ & 34,6 & 46,1 & $+33,2$ \\
\hline $\begin{array}{l}\text { Handikappomsorg: antal personer med } \\
\text { insatser, varav ... }\end{array}$ & 74800 & 92900 & $+24,2$ \\
\hline ...hemtjänst SoL & 14500 & 17900 & $+23,4$ \\
\hline ...boende Sol & 5500 & 5800 & $+5,5$ \\
\hline$\ldots$ LSS & 45500 & 55800 & $+22,6$ \\
\hline ...LASS (personlig assistans) & 9300 & 13400 & $+44,0$ \\
\hline
\end{tabular}

Källor: Socialstyrelsen 2007a, b, c och d samt RFV 2001 och Försäkringskassan 2006.

1 Eftersom en individ samtidigt kan få insatser enligt såväl SoL som LSS och LASS är det sammanlagda antalet personer med insatser något överskattat vid båda mättillfällena. I uppgifterna om resurser och insatser för personer med funktionshinder ingår insatser även för ett mindre antal personer över 65 år: år 2000 gäller detta 3100 personer med LSS-insatser, år 2005 3900 personer med LSS-insatser samt 1250 personer med personlig assistans. En del av ökningen inom LASS beror på att sedan år 2001 får personer över 65 år behålla (men inte utöka) redan beviljad assistans. 
sarna i LSS, inte fick del av förbättringarna. Det är inte möjligt att få en samlad bild av hur det sammanlagda antalet funktionshindrade personer med omsorgstjänster förändrades under 1990-talet, men sannolikt ökade handikappomsorgen även antalsmässigt (a.a. s. 110).

Äldreomsorgens resurser, räknat per invånare 80 år och äldre, minskade mellan 1990 och 2000 med 15 procent (SOU 2004:68 s. 147). Andelen äldre med äldreomsorg började minska kraftigt på 1980talet och minskningen fortsatte under 1990-talet. Bland de äldsta, 80 år och äldre, minskade andelen med någon form av insats från den offentliga äldreomsorgen från 62 till 43 procent mellan 1980 och 1999. Det är framför allt hemtjänstandelen som minskade drastiskt (SOU 2001:79). Den kraftiga minskningen kan inte förklaras av en motsvarande förbättring av de äldstas hälsa och funktionsförmåga (Batljan \& Lagergren 2000, Thorslund et al. 2004, Larsson 2006).

Resurserna för äldreomsorgen måste också sättas i relation till sjukvårdens resurser, vilka minskade påtagligt under 1990talet. Antalet vårdplatser nära nog halverades och vårdtidens längd förkortades kraftigt, särskilt för äldre patienter, vilket ökade pressen på den kommunala äldreomsorgen. Kommunens insatser kom därigenom att koncentreras till äldre med mer omfattande hjälpbehov (SOU 2001:79).

Som framgår av Tabell 1 har tendenserna från 1990-talet i stort sett fortsatt under de fem första åren av 2000-talet. Resurserna till handikappomsorgen $i$ form av insatser enligt Socialtjänstlagen, LSS och LASS, ökade med drygt 11 miljarder kronor eller 33 procent, medan äldreomsorgens resur- ser under samma tid minskade med ca 3 miljarder kronor eller 3 procent. Minskningen blir mer märkbar om man noterar att de äldsta i befolkningen (80+) under samma tid ökade med ca 35000 personer: i relation till antalet 80 år och äldre i befolkningen minskade äldreomsorgens resurser med 10 procent.

Om vi ser till antalet personer som får del av insatserna sker en viss minskning på äldreomsorgssidan, men framförallt har det skett förändringar inom verksamheten: antalet personer som bodde i äldreboenden (servicehus, ålderdomshem, sjukhem, gruppboenden) minskade med 15 procent medan hemtjänsten ökade med 12 procent. Förskjutningen från äldreboenden till hembaserad omsorg är ett trendbrott jämfört med utvecklingen under 1980- och 1990talen, och minskningen av antalet boendeplatser för äldre blev en uppmärksammad valfråga 2006. Det finns idag en kraftig opinion för en (åter)utbyggnad av äldreboenden (Socialstyrelsen 2007c).

På handikappomsorgens område ökade antalet personer med insatser med 24 procent. Personlig assistans är den del av handikappomsorgen som har ökat mest, oavsett om man fokuserar på kostnader eller antal som får del av verksamheten. Ökningen har varit i stort sett obruten sedan reformen infördes 1994: mellan 1994 och 2005 har antalet brukare ökat med 130 procent, det genomsnittliga antalet timmar med 57 procent och kostnaden i fasta priser med 330 procent (Socialstyrelsen 2007e).

Personlig assistans skiljer sig påtagligt från andra insatser till hemmaboende personer när det gäller insatsens omfattning. År 2005 hade en person med personlig

Marta Szebehely \& Gun-Britt Trydegård: Omsorgstjänster för äldre och funktionshindrade... 
assistans i genomsnitt 97 timmar per vecka (a.a. s. 13), vilket kan jämföras med cirka sju timmar per vecka för en person med hemtjänst - och här föreligger ingen större skillnad mellan personer över och under 65 år (Socialstyrelsen 2007b och d).

Den kostnadsmässiga expansionen inom personlig assistans, som har fått mycket uppmärksamhet under senare år (se t.ex. Assistanskommitténs betänkande SOU 2005:100 och Socialstyrelsen 2007e), är således inte representativ för utvecklingen inom andra delar av handikappomsorgen. Men även om det finns stora skillnader inom verksamheterna är det ändå tydligt att äldre- respektive handikappomsorgen sammantaget har utvecklats i olika riktning under 2000-talet (liksom under decenniet dessförinnan).

\section{Arbetsvillkor och omsorgskvalitet inom äldre- och handikappomsorgen}

De påtagligt skilda trenderna när det gäller resursutvecklingen inom äldre- respektive funktionshindersområdet väcker frågor om verksamheterna har utvecklats åt skilda håll också när det gäller insatsernas kvalitet och personalens arbetsvillkor.

När det gäller äldreomsorgen finns det mer kunskap om personalens situation än hur de äldre själva ser på den hjälp de får, och det finns mer kunskap om hemtjänst än om äldreboenden. Enligt flera studier av hemtjänsten har de senare årens resursmässiga och organisatoriska förändringar påverkat verksamheten negativt, både ur personalens och hjälptagarnas perspektiv (för översikter av den nordiska forskningen på området se Højlund 2005 och Trydegård 2005). Även om de flesta hemtjänstmottagare på ett allmänt plan är nöjda med hjälpen tycks kritiken ha ökat, framför allt när det gäller tidsbrist, bristande personkontinuitet och minskade möjligheter att påverka hur hjälpen utförs (se ex. Hammarström 2002, Socialstyrelsen 2006, Fried 2007). Flera studier tyder på att också äldreomsorgspersonalens arbetsvillkor försämrades under 1990-talet, framför allt ökade arbetsbelastningen samtidigt som möjligheten att möta arbetskraven minskade (Tegsjö et al. 2000, Bäckman 2001, Gustafsson \& Szebehely 2005).

När det gäller samhällets stödinsatser för personer med funktionshinder är det ingen tvekan om att assistansreformen har inneburit väsentligt förbättrade villkor för dem som beviljats personlig assistans (Socialstyrelsen 1997, Jacobson 2000, Selander 2003), medan mindre är känt om hur andra grupper av funktionshindrade personer ser på de insatser som de får del av (Barron et al. 2000). Det finns mycket få studier av personalen inom handikappomsorgen, med undantag för de personliga assistenterna (t.ex. Arbetsmiljöverket 2002, Hugemark \& Wahlström 2002, Larsson 2004). Studierna visar bland annat att personalomsättningen är hög och att arbetet som personlig assistent ofta upplevs som svåravgränsat och ensamt men samtidigt som självständigt och meningsfullt.

Så vitt vi känner till finns inga jämförande studier av äldreomsorg och handikappomsorg som verksamhet och arbetsplats (se dock Ahnlund \& Johansson 2006). En pågående studie, baserad på en enkät till 
ett slumpvis urval av Kommunals medlemmar, ger dock vissa möjligheter att jämföra de båda verksamhetsgrenarna. ${ }^{2}$ I studien är det personalen som kommer till tals, men resultaten ger indirekt också en bild av brukarnas situation, se Tabell 2.

2 Projektet NORDCARE - Omsorgsvardag i Norden - är en enkätundersökning som under 2005 sändes till ett slumpvis urval av fackligt ansluten äldre- och handikappomsorgspersonal i Norden. Projektet är finansierat av FAS och
De svarsmönster som redovisas i Tabell 2 pekar på mycket stora skillnader i hur personalen ser på sina arbetsvillkor och möjligheten att ge god omsorg inom äldre- respektive handikappomsorgen. Både när det gäller arbetsbelastning och relationen till

leds av Marta Szebehely, se vidare www.fas. forskning.se/projekt. I denna artikel redovisas resultat enbart från den svenska delen av studien (svarsfrekvens 66 procent).

\section{Tabell 2.}

Arbetsvillkor inom äldre- och handikappomsorg. Vårdbiträden, undersköterskor, vårdare och personliga assistenter anställda inom äldre- och handikappomsorg. Ar 2005.

\begin{tabular}{|c|c|c|c|c|}
\hline \multirow[b]{2}{*}{ Andel (\%) som... } & \multicolumn{2}{|c|}{ Äldreomsorg } & \multicolumn{2}{|c|}{ Handikappomsorg } \\
\hline & $\begin{array}{l}\text { Boende- } \\
\text { former } \\
(n=360)\end{array}$ & $\begin{array}{c}\text { Hemtjänst } \\
(n=\mid 77)\end{array}$ & $\begin{array}{l}\text { Boende- } \\
\text { former } \\
(n=76)\end{array}$ & $\begin{array}{c}\text { Personlig } \\
\text { assistans } \\
(\mathrm{n}=92)\end{array}$ \\
\hline $\begin{array}{l}\text {... har för mycket att göra i arbetet } \\
\text { (oftast) }\end{array}$ & 42 & 37 & 9 & 6 \\
\hline $\begin{array}{l}\text {... känner sig otillräcklig för att hjälp- } \\
\text { tagarna inte făr rimlig hjälp (oftast) }\end{array}$ & 32 & 22 & 13 & 9 \\
\hline \multicolumn{5}{|l|}{$\begin{array}{l}\text {... anser att under senare år har arbets- } \\
\text { villkoren i stort sett: }\end{array}$} \\
\hline förbättrats & 7 & 21 & 29 & 24 \\
\hline ingen skillnad & 40 & 37 & 53 & 57 \\
\hline försämrats & 43 & 41 & 18 & 20 \\
\hline \multicolumn{5}{|l|}{$\begin{array}{l}\text {... anser att under senare år har möj- } \\
\text { ligheten att möta hjälptagarnas behov i } \\
\text { stort sett: }\end{array}$} \\
\hline förbättrats & 19 & 17 & 25 & 35 \\
\hline ingen skillnad & 41 & 36 & 48 & 57 \\
\hline försämrats & 39 & 48 & 26 & 9 \\
\hline
\end{tabular}

Källa: Egna analyser av enkätstudie NORDCARE.

Marta Szebehely \& Gun-Britt Trydegård: Omsorgstjänster för äldre och funktionshindrade... 
hjälptagaren framstår äldreomsorgen som en betydligt mer problematisk verksamhet. ${ }^{3}$

Den kanske allra mest iögonenfallande skillnaden gäller hur hemtjänstpersonal och personliga assistenter ser på sina möjligheter att möta hjälptagarens behov. Nära hälften av hemtjänstpersonalen anser att dessa möjligheter har försämrats, jämfört med ungefär var tionde personlig assistent. Denna skillnad är rimlig att relatera både till verksamheternas resursutveckling och till det dagliga arbetets organisering. Personliga assistenter arbetar i allmänhet hos en och samma person under hela arbetsdagen, medan hemtjänstpersonalen i genomsnitt möter nio hjälptagare under en arbetsdag (uppgift från NORDCARE). Den personliga assistentens arbetsdag är i stort sett inte i förväg styrd av regler, rutiner och schemalagda arbetsuppgifter, medan hemtjänstpersonalen under senare år har fått alltmer detaljerade biståndsbeslut att följa. Omfattande hemtjänstforskning har visat att god omsorg förutsätter tid men också att personalen har ett tillräckligt stort handlingsutrymme för att kunna möta hjälptagarens varierande och ofta oförutsedda behov (se Szebehely 2006a). Mycket tyder på att både tiden och handlingsutrymmet har minskat inom hemtjänsten och ökat inom den personliga assistansverksamheten.

3 När det gäller andra aspekter av arbetsvillkoren, t.ex. anställningstrygghet och psykosocial arbetsmiljö är skillnaderna mellan äldreoch handikappomsorg betydligt mindre och går ibland i motsatt riktning (uppgifter från NORDCARE).

\section{Offentliga och privata utförare av omsorgstjänster}

En tydlig tendens under 1990-talet var den ökande privatiseringen av välfärdstjänsterna. Genom en ändring i kommunallagen (SFS 1991:900) gavs kommunerna möjlighet att lämna över utförandet av tjänsterna till privata firmor av olika slag, genom antingen entreprenader eller någon form av kundvalssystem. I en studie för Kommittén Välfärdsbokslut visades att andelen anställda i alternativ drift inom de kommunala välfärdstjänsterna mer än fördubblades under 1990-talet. Den största relativa ökningen skedde inom äldre- och handikappomsorgen - en uppgång på 400 procent - och år 2000 var ca 13 procent anställda i privata företag, varav drygt 3 procent icke vinstsyftande. Det var stora, vinstsyftande aktiebolag som dominerade bilden, medan t.ex. ideella organisationer och kooperativ var mindre vanliga inom äldre- och handikappomsorgen (Trydegård 2001).

Motsvarande analyser av utvecklingen under 2000-talet är tyvärr inte möjliga att göra på grund av att de s.k. branschkoderna i statistiken har förändrats, och vi får söka uppgifter om utvecklingen av alternativa driftformer på andra håll. Statistiska Centralbyrån visar att det skett en kraftig ökning av privat drift inom välfärdstjänsterna totalt sedan slutet på 1990-talet, och särskilt inom vård, omsorg och annan socialtjänst (t.ex. missbrukarvård och barnavård). Det är fortfarande de privatägda företagen som har ökat mest; betydligt mer än de ideella verksamheterna (SCB 2006). Inom äldreomsorgen finns det dock en ten- 
dens att ökningen av andelen privata utförare bromsats upp, konstateras i en nyligen publicerad kartläggning från Delegationen för mångfald inom vård och omsorg (SOU 2007:37). Privat drift inom äldreomsorgen, som under 1990-talet i mycket var en storstadsföreteelse, har nu blivit vanligare också i glesbygd och i industrikommuner (Socialstyrelsen 2004a). Skillnaderna mellan kommunerna är dock fortfarande stora: några av Stockholms förorter har mer än hälften av äldreomsorgen utlagd på privata vårdgivare, jämfört med mindre än en procent i ca en tredjedel av landets kommuner (Socialstyrelsen 2007f).

Av Socialstyrelsens brukarstatistik om äldreomsorgen för 2006 (Socialstyrelsen 2007d) framgår att 11 procent av dem som var beviljade hemtjänst fick sådan i privat regi, att jämföra med 7 procent år 2000 . Ca 14 procent bodde i äldreboenden som drevs i enskild regi att jämföra med elva procent år 2000. Brukarstatistiken för insatser enligt LSS innehåller inga uppgifter om privata utförare, men när det gäller den statliga assistansersättningen uppger Försäkringskassan (2005) att kommunerna år 2004 anordnade personlig assistans för drygt 60 procent av de assistansberättigade, en minskning med 10 procentenheter över tio år. En oförändrad andel (12 procent) anlitade kooperativ och andra icke-vinstsyftande organisationer medan andelen som anlitade vinstsyftande företag har ökat och omfattade 24 procent år 2004. En oförändrad andel (4 procent) av de assistansberättigade är själva arbetsgivare för sina assistenter.

Personalstatistiken gav tidigare inte möjlighet att särskilja äldreomsorgen från handikappomsorgen. Det var först 2003, då en ny näringsgrensindelning infördes, som det blev möjligt att skilja de två omsorgsområdena åt och det blev då också möjligt att skilja öppna verksamheter (hemtjänst, personlig assistans) från olika boendeformer för äldre resp. för personer med funktionshinder. Det visar sig då ganska olika mönster i de två omsorgstjänsterna. Alternativ drift är betydligt vanligare inom handikappomsorgen än inom äldreomsorgen, och är särskilt omfattande inom de öppna handikappverksamheterna. Tabell 3 visar att år 2005 var drygt 60 procent av personalen inom handikappomsorgens öppna verksamheter anställda i privata företag. Även om non profit-företag som kooperativ och ideella föreningar förekom betydligt oftare än inom äldreomsorgen, svarade de vinstsyftande företagen för merparten av den alternativa driften också inom handikappomsorgen.

Att mer än 60 procent av de öppna verksamheterna inom handikappomsorgen utförs av anställda i privat regi är en överraskande hög siffra som inte motsvarar övriga uppgifter vi haft tillgång till, t.ex. om andelen privata assistansanordnare (Försäkringskassan 2005, SOU 2005:100). Sifferuppgifterna om privat drift i äldreomsorgen är i gengäld avsevärt lägre än vad som framgår av brukarstatistiken (se ovan). En tänkbar förklaring kan vara att kommunerna inte särrapporterar de anställda som arbetar med yngre funktionshindrade utan låter dem ingå i statistiken över äldreomsorgspersonal. Personal med kommunal arbetsgivare blir i så fall underrapporterad i handikappomsorgen men överrepresenterad i äldreomsorgen. Osäkerheten i

Marta Szebehely \& Gun-Britt Trydegård: Omsorgstjänster för äldre och funktionshindrade... 
uppgifterna pekar i vart fall på behovet av mera stabil och utförlig statistik när det gäller den privata driften. Den reguljära verksamhetsstatistiken gällande LSS-insatser saknar helt uppgifter om omfattningen av privat drift, och i äldreomsorgsstatistiken saknas uppgifter om verksamheten drivs av vinstsyftande eller icke vinstsyftande företag. Sveriges Kommuner och Landsting redovisar enbart den kommunalt anställda personalen och inte den privat anställda. De tydliga kunskapsluckor om omfattningen av omsorgstjänsternas privatisering, som påtalades av Kommittén Välfärdsbokslut (SOU 2001:79) kvarstår med andra ord.
Det är fortfarande också brist på kunskaper om vad den ökade privatiseringen har inneburit för brukarna, för personalen och för kommunerna. Socialstyrelsen (2004b) menar att det inte med tillgängliga data går att belägga att konkurrensutsättning av äldreomsorgen leder till att kommunens kostnader blir lägre, snarare finns en tendens till det motsatta. Brukarnas syn på kvaliteten i privat och offentlig äldreomsorg tycks inte heller skilja sig åt enligt samma undersökning. Stockholms stad undersökte i en enkät till äldreomsorgens hemtjänstmottagare hur den s.k. kundvalsmodellen fungerat (Fried 2007). Det var fyra av tio som hade valt hemtjänstutförare själva - andra

\section{Tabell 3.}

Alternativ drift inom äldre- och handikappomsorgen, andel anställda (\%), 2005.

\begin{tabular}{lccc}
\hline & $\begin{array}{c}\text { Icke vinst- } \\
\text { syftande }\end{array}$ & Vinst-syftande & $\begin{array}{c}\text { Totalt alternativ } \\
\text { drift }\end{array}$ \\
\hline Äldreomsorg & & & \\
Boenden & 1,6 & 8,9 & 10,5 \\
Öppna verksamheter & 0,6 & 4,9 & 5,5 \\
Totalt & 1,2 & 7,2 & 8,4 \\
Handikappomsorg & & & \\
Boenden & 5,0 & 10,7 & 15,7 \\
Öppna verksamheter & 19,2 & 43,6 & 62,8 \\
Totalt & 10,6 & 23,6 & 34,2 \\
Äldre- och handikappomsorg, totalt & 3,5 & 11,2 & 14,7 \\
\hline
\end{tabular}

Källa: Registerbaserad arbetsmarknadsstatistik, RAMS. ${ }^{4}$

4 Den registerbaserade arbetsmarknadsstatistiken, RAMS, bygger på de kontrolluppgifter som varje arbetsgivare är skyldig att lämna till Skatteverket för de personer som fått kontant bruttolön eller annan ersättning utbetald under året. Tabellen bygger på uppgifter från Ingegerd Berggren, SCB. 
hade fått hjälp av biståndshandläggare eller anhöriga. Ca 15 procent hade någon gång bytt utförare, och den vanligaste anledningen var missnöje med utföraren, följt av att man föredrog kommunal hemtjänst och att man valt att följa sin personal som bytt arbetsgivare. Utredningen fann ingen skillnad i kvalitén mellan hjälp i kommunal eller privat regi. Enligt en utvärdering av kundvalsmodellen i Stockholm (Hjalmarsson 2003) var många äldre med mindre omfattande hjälpbehov i princip positiva till möjligheten att välja, men de ville framför allt kunna påverka vem som kommer och vad som ska göras vid varje hjälptillfälle, snarare än att välja mellan olika utförarorganisationer. För de skröpligaste hjälptagarna framstod valfriheten ofta inte som ett positivt alternativ.

Den statliga Assistanskommittén (SOU 2005:100) visade med hjälp av en enkät till assistansberättigade att assistansen fungerade väl för de allra flesta, men att det fanns vissa kvalitetsskillnader som hade att göra med driftformen. De som hade kommunal assistansanordnare hade mindre inflytande över assistansen och mindre möjligheter att bestämma över arbetsuppgifterna som skulle utföras, än de som hade valt brukarkooperativ eller annan privatdriven serviceorganisation.

I en kunskapsöversikt av den nordiska äldreomsorgsforskningen påtalas de många kunskapsluckorna som finns när det gäller personalens upplevelser och erfarenheter av att arbeta i marknadsdrivna eller marknadsliknande driftformer (Trydegård 2005). En senare svensk studie av all äldreomsorgspersonal $i$ åtta kommuner med äldreomsorg i såväl offentlig som privat drift (Gustafsson \& Szebehely 2007) visade dock att inga entydiga arbetsmiljöeffekter kunde kopplas till driftformen, men att en negativ inställning till privat drift fanns hos omsorgsarbetarna - med undantag av den grupp privatanställda som ansåg sig ha en god arbetsmiljö på sin egen arbetsplats.

På funktionshindersidan är det än mera tunnsått med studier av vad driftformen betyder för personalen. Arbetsmiljöverket (2002) påpekar i en rapport den svagare anställningstryggheten för personliga assistenter som är anställda hos privata företag. Assistenterna blir ofta projektanställda, där brukaren utgör själva projektet, vilket innebär att om brukaren byter assistansanordnare, flyttar till institution eller avlider, upphör projektet. Denna otrygghet kan föra med sig att assistenterna inte vågar påpeka eventuella brister i arbetsmiljön och ställa krav av rädsla för att bli oense med brukaren och uppsagd. Riksrevisionsverket (2004, se även Hugemark 2006) påtalar att oseriösa privata assistansanordnare kan försöka öka sina vinstmarginaler genom att hålla nere kostnaderna för löner, ob-tillägg, utbildning och handledning.

\section{Gränsomdragningar av kommunens, närståendes och marknadens insatser}

Vilken slags hjälp får personer under respektive över 65 år som bor hemma och behöver hjälp i sin vardag? Hur många får hjälp av den offentligt finansierade hjälpapparaten, hur många får hjälp av närstående och hur många köper privat hjälp på marknaden som de betalar ur egen ficka? Skiljer sig

Marta Szebehely \& Gun-Britt Trydegård: Omsorgstjänster för äldre och funktionshindrade... 
hjälpmönstren mellan yngre och äldre? Och framför allt: hur har hjälpmönstren förändrats över tid för de båda grupperna?

Kommittén Välfärdsbokslut redovisade utvecklingen under 1990-talet när det gäller dessa frågor (Szebehely et al. 2001). Analysen baserades på SCB:s levnadsförhållandestudier (ULF) 1988-89 och 1998-99. Där visades att de yngre (16-64 år) hade i stort sett samma hjälpmönster vid båda tidpunkterna. Bland äldre (65-84 år) hade däremot den offentliga hjälpen minskat, samtidigt som anhörigas och vänners insatser hade ökat, liksom hjälp köpt på den privata marknaden (a.a. kapitel 6). I kommitténs slutbetänkande (SOU 2001:79 s. 77) visades att dessa trender hade skilda klassförtecken: informell hjälp hade ökat främst bland äldre med kortare utbildning, medan privat köpt hjälp hade ökat främst bland äldre med längre utbildning. Förskjutningen inom omsorgen om äldre från offentlig hjälp till informell hjälp respektive till hjälp köpt på marknaden kan betecknas som en trend mot informalisering respektive marknadisering (a.a. s. 113).

I det följande ska vi föra fram dessa analyser. Vi jämför 2004-05 med slutet av 1980talet, vilket ger oss möjlighet att inkludera även de allra äldsta ( 85 år+). ${ }^{5}$ Samtliga analyser i detta avsnitt gäller hemmaboende personer som har nedsatt rörelseförmåga, nedsatt syn eller andra funktionshinder/ långvarig sjukdom och som behöver hjälp med minst en av följande uppgifter: städ-

5 Sedan 2002 genomförs ULF utan övre åldersgräns; tidigare exkluderades personer över 84 år från undersökningen med undantag för 1988-89. ning, inköp, tvätt, matlagning (huslig hjälp) eller bad/dusch, av-/påklädning, hjälp till toaletten (personlig hjälp); (för definitioner och avgränsningar, se Szebehely et al. 2001 s. 160). ${ }^{6}$

Vi urskiljer fyra kategorier av hjälpgivare: make/maka eller annan hushaillsmedlem, andra närstående utanför hushället (familjemedlemmar, släktingar, vänner eller grannar), hemtjänst eller personlig assistans (oavsett om insatsen utförs i kommunal eller privat regi) samt marknaden (hjälp som den enskilde köper på en vit eller svart marknad och betalar helt ur egen ficka). ${ }^{7}$

I de följande analyserna redovisar vi dels andelar som uppger att de får hjälp från respektive hjälpgivare, dels den andel som uppger att de får enbart informell hjälp, dvs. hjälp enbart från en make/maka eller annan närstående inom eller utom det egna hushållet. Observera att många (särskilt bland de äldre) får hjälp från flera olika håll.

6 Detta sätt att mäta innebär sannolikt en underskattning av anhörigas omsorg eftersom sådana insatser som transporter, tillsyn, känslomässigt stöd eller kontakt med sjukvården (som ofta är anhörigas ansvar) inte efterfrågas (se Jeppsson Grassman 2003). I ULF ges ingen information om vilka insatser de olika hjälpgivarna bidrar med.

7 Privat köpt hjälp är endast möjlig att särskilja från 'annan' (ospecificerad) hjälp i ULF-undersökningarna vid det senare mättillfället. Av de 5 procent av de yngre som enligt Tabell 4 får privat/annan hjälp köper 4 procent privat hjälp; av de 13 procent av de äldre (65 år+) som får privat/annan hjälp köper 10 procent privat hjälp. Troligen fångar kategorin 'privat köpt/ annan hjälp' vid båda mättillfällena till största delen hjälp köpt på marknaden och betald direkt av den hjälpbehövande. 
Noterbart är också att i denna typ av undersökningar är det alltid mycket få (högst 1-2 procent) som uppger att de inte får hjälp över huvud taget trots hjälpbehov.

När det gäller de yngre (16-64 år) kan vi först och främst i Tabell 4 konstatera att yngre funktionshindrade personer som behöver hjälp i vardagen oftast får hjälp av en hushållsmedlem samt att denna form av hjälp har ökat. Sammantaget drygt 80 procent av de yngre funktionshindrade får enbart informell hjälp (ingen förändring över tid). Ungefär var åttonde får offentlig hjälp och var tjugonde får privat/annan hjälp. Dessa hjälpformer är i stort sett lika vanliga 2004-05 som vid 1980-talets slut.

Också bland de äldre (65 år+) är informella hjälpinsatser omfattande, men inte lika dominerande som bland de yngre. Ungefär hälften får enbart informell hjälp (ingen förändring över tid). När det gäller hjälp från hjälpgivare utanför den äldres eget hushåll har hjälpmönstren förändrats: andelen som får hjälp från hemtjänsten har minskat (från 47 till 40 procent), samtidigt som andelen som får hjälp av närstående utanför hushållet har ökat (från 41 till 51 procent). Cirka 12-13 procent köper privat hjälp eller får hjälp på annat sätt vid båda mättillfällena. Det innebär att den informa lisering av äldreomsorgen under 1990-talet som konstaterades av Kommittén Välfärdsbokslut (SOU 2001:79) har fortsatt, medan det inte längre finns några tecken på ökad marknadisering - andelen med privat köpt hjälp som ökade under 1990-talet har minskat något under 2000-talet.

I Tabell 5 redovisas hjälpgivare bland yngre och äldre med olika omfattande hjälpbehov.

Bland de yngre kan vi först konstatera att vid slutet av 1980-talet fanns det inga större skillnader i hjälpmönster mellan personer med mer eller mindre omfattande hjälpbehov. År 2004-05 har detta förändrats: den offentliga hjälpen har minskat bland dem

\section{Tabell 4.}

Hjälpgivare bland hemmaboende yngre och äldre personer med funktionshinder och behov av hjälp i vardagen, 1988-89 och 2004-05.

\begin{tabular}{lcc|cc}
\hline Andel (\%) som får hjälp från ... & \multicolumn{2}{c}{ Yngre (16- 64 år) } & \multicolumn{2}{c}{ Äldre (65 år+) } \\
\hline & $\begin{array}{c}1988-89 \\
(\mathrm{n}=291)\end{array}$ & $\begin{array}{c}2004-05 \\
(\mathrm{n}=249)\end{array}$ & $\begin{array}{c}1988-89 \\
(\mathrm{n}=813)\end{array}$ & $\begin{array}{c}2004-05 \\
(\mathrm{n}=349)\end{array}$ \\
\hline $\begin{array}{l}\text {.. hushållsmedlem } \\
\text {... närstående utanför hushållet }\end{array}$ & 69 & $77 *$ & 42 & 42 \\
$\begin{array}{l}\text {... enbart informell hjälp (hushållsmedlem } \\
\text { eller andra närstående) }\end{array}$ & 34 & 35 & 41 & 51 ** \\
$\begin{array}{l}\text {...hemtjänst/personlig assistent } \\
\text {... privat köpt/ annan hjälp }\end{array}$ & 15 & 82 & 49 & 49 \\
\hline
\end{tabular}

Källa: Egna analyser av SCB:s ULF-undersökningar. ${ }^{* *} \mathrm{p}<0,01 ;{ }^{*} \mathrm{p}<0,05$.

Marta Szebehely \& Gun-Britt Trydegård: Omsorgstjänster för äldre och funktionshindrade... 
med mindre omfattande hjälpbehov och ökat bland dem med större behov. Idag är skillnaden påtaglig mellan de båda grupperna: bland yngre med omfattande hjälpbehov har 29 procent offentlig hjälp (varav drygt hälften har personlig assistans), jämfört med 8 procent bland dem med mindre behov. En konsekvens av detta är att det idag är fler bland de yngre med mindre hjälpbehov som får enbart informell hjälp (en signifikant ökning från 81 till 89 procent). Bland de yngre med omfattande hjälpbehov är det i stället färre som får enbart informell hjälp (en signifikant minskning från 80 till 62 procent).

Även bland de äldre finns det ett behovs-

\section{Tabell 5.}

Hjälpgivare bland hemmaboende yngre och äldre personer med funktionshinder efter hjälpbehov, 1988-89 och 2004-05.

\begin{tabular}{|c|c|c|c|c|}
\hline \multirow[b]{3}{*}{ Andel (\%) som får hjälp från ... } & \multicolumn{4}{|c|}{ Yngre (16- 64 år) } \\
\hline & \multicolumn{2}{|c|}{ Med mindre hjälpbehov } & \multicolumn{2}{|c|}{ Med större hjälpbehov } \\
\hline & $\begin{array}{l}1988-89 \\
(n=233)\end{array}$ & $\begin{array}{l}2004-05 \\
(n=186)\end{array}$ & $\begin{array}{l}1988-89 \\
(n=57)\end{array}$ & $\begin{array}{l}2004-05 \\
(n=63)\end{array}$ \\
\hline ...hushållsmedlem & 69 & 76 & 66 & 79 \\
\hline ...närstående utanför hushållet & 34 & 34 & 34 & 40 \\
\hline $\begin{array}{l}\text {...enbart informell hjälp (hushållsmedlem } \\
\text { eller andra närstående) }\end{array}$ & 81 & $89 *$ & 80 & $62 *$ \\
\hline ... hemtjänst/ personlig assistent & 14 & $8^{\top}$ & 18 & $29^{\top}$ \\
\hline \multirow[t]{3}{*}{...privat köpt/ annan hjälp } & 6 & 4 & 9 & 10 \\
\hline & \multicolumn{4}{|c|}{ Äldre (65 år+) } \\
\hline & \multicolumn{2}{|c|}{ Med mindre hjälpbehov } & \multicolumn{2}{|c|}{ Med större hjälpbehov } \\
\hline Andel (\%) som får hjälp från ... & $\begin{array}{l}1988-89 \\
(n=575)\end{array}$ & $\begin{array}{l}2004-05 \\
(n=236)\end{array}$ & $\begin{array}{l}1988-89 \\
(n=235)\end{array}$ & $\begin{array}{l}2004-05 \\
(n=\mid 12)\end{array}$ \\
\hline ...hushållsmedlem & 37 & 34 & 54 & 57 \\
\hline ...närstående utanför hushållet & 42 & $50 *$ & 38 & $53 * *$ \\
\hline $\begin{array}{l}\text {...enbart informell hjälp (hushållsmedlem } \\
\text { eller andra närstående) }\end{array}$ & 51 & 53 & 46 & 44 \\
\hline ...hemtjänst/ personlig assistent & 44 & 34 *** & 52 & 51 \\
\hline ...privat köpt/ annan hjälp & || & 15 & 13 & 8 \\
\hline
\end{tabular}

Källa: Egna analyser av SCB:s ULF-undersökningar. ${ }^{* *} \mathrm{p}<0,01 ;{ }^{*} \mathrm{p}<0,05 ;{ }^{\mathrm{T}}<0,10$.

8 Mindre hjälpbehov har de som behöver hjälp med högst tre husliga uppgifter, större hjälpbehov har de som behöver hjälp med alla fyra husliga uppgifter och ofta också personlig hjälp med bad och dusch eller liknande. 
relaterat mönster när det gäller offentlig hjälp: hemtjänst är vanligare bland äldre med omfattande behov. Över tid är andelen med hemtjänst oförändrad bland dem med större behov och har minskat bland dem med mindre behov. I båda grupperna har dock omsorgsinsatser från närstående utanför hushållet ökat - mest bland dem med större behov: en ökning från 38 till 53 procent, se Tabell 5. Om vi ser närmare på dessa trender visar det sig att närståendes insatser framför allt har ersatt den uteblivna offentliga hjälpen bland äldre med mindre behov och kompletterar i ökad utsträckning den offentliga hjälpen bland äldre med större behov (visas ej i tabellen). ${ }^{9}$

\section{Utbildningsrelaterade hjälpmönster bland äldre}

Yngre funktionshindrade med högre och lägre utbildning har likartade hjälpmönster. Däremot finns det ett tydligt utbildningsrelaterat hjälpmönster bland de äldre. Detta gäller inte hemtjänsten som har minskat på ungefär samma sätt bland äldre med förgymnasial utbildning och äldre med minst gymnasial utbildning. Däremot är hjälp från närstående utanför hushållet betydligt vanligare och har ökat mer bland äldre med förgymnasial utbildning än bland dem med

9 Bland äldre med mindre omfattande behov har andelen som får hjälp av närstående utanför hushållet men ej kommunal hjälp ökat från 25 till 34 procent; bland äldre med mer omfattande hjälpbehov har andelen som får både kommunal hjälp och hjälp från närstående utanför hushållet ökat från 25 till 36 procent. högre utbildning: år 1988-89 fick 43 procent av äldre med kortare utbildning hjälp av närstående som de inte bodde tillsammans med, år 2004-05 hade andelen ökat till 58 procent $(\mathrm{p}<0,001)$. Bland äldre med högre utbildning var motsvarande andelar 33 respektive 37 (förändringen ej signifikant). Särskilt påtaglig är ökningen av närståendes insatser bland lågutbildade äldre med stora omsorgsbehov: en ökning från 37 procent vid slutet av 1980-talet till 62 procent år 2004-05 ( $<<0,001)$; bland dem med högre utbildning är motsvarande andelar 42 respektive 36 procent (förändring över tid ej signifikant). När det gäller omsorg från närstående utanför hushållet är således skillnaderna mellan äldre med olika utbildningsbakgrund betydligt större idag än vid 1980-talets slut.

Ett omvänt utbildningsrelaterat mönster gäller privat köpt hjälp. Andelen med privat/annan hjälp har ökat från 14 till 19 procent bland äldre med högre utbildning; bland äldre med lägre utbildning var motsvarande andelar 11 respektive 9 procent. Förändringarna över tid är inte signifikanta, vilket innebär att den tendens till marknadisering av äldreomsorgen bland äldre med högre utbildning som vi kunde notera vid slutet av 1990-talet (SOU 2001:79) inte längre är lika påtaglig. Samtidigt kan vi konstatera att skillnaden mellan utbildningsgrupperna i användning av privat köpt hjälp är betydligt större idag än vid 1980-talets slut.

Dessa ökade utbildningsrelaterade skillnader i hjälpmönster bland de äldre väcker en fråga om skillnaderna (och förändringarna) svarar mot de äldres egna önskemål. Motsvarar den ökade anhörighjälpen de

Marta Szebehely \& Gun-Britt Trydegård: Omsorgstjänster för äldre och funktionshindrade... 
äldres egna önskemål, och är äldre med lägre utbildning mer positiva till anhörighjälp än äldre med högre utbildning?

ULF-undersökningarna ger inte möjlighet att besvara dessa frågor, men med hjälp av en studie bland hemmaboende äldre (75 år+) som Socialstyrelsen genomförde år 2000 är det möjligt att belysa de äldres omsorgspreferenser. I en första redovisning av studien (Socialstyrelsen 2000) noteras att de äldres önskemål endast förändrats marginellt mellan 1994 och 2000, samtidigt som andelen med hemtjänst minskat påtagligt och anhöriga "fyllt ut" tomrummet. Den informalisering av äldreomsorgen som även Socialstyrelsen kunde notera kan således inte förklaras av ändrade preferenser.
I Tabell 6 belyses omsorgspreferenser bland äldre med högre och lägre utbildning med hjälp av Socialstyrelsens undersökning.

Ungefär hälften av de äldre föredrar den offentliga sektorns hjälp, och en dryg fjärdedel föredrar hjälp av en make eller maka. Äldre med lägre utbildning är något mer positiva till offentlig hjälp än äldre med högre utbildning, medan äldre med högre utbildning är mer positiva till såväl entreprenadiserad hemtjänst som hjälp köpt på den privata marknaden, finansierad helt ur egen ficka. När det gäller hjälp från närstående finns det däremot knappast några utbildningsrelaterade skillnader: ungefär var tionde äldre person - oav-

\section{Tabell 6.}

Omsorgspreferenser för huslig resp. personlig hjälp efter utbildningsnivå. Hemmaboende äldre 75 år $r$, år 2000.

\begin{tabular}{lcc|cc}
\hline Föredragen hjälpgivare (\%) & \multicolumn{2}{|c|}{ Hjälp med tvätt eller städning } & \multicolumn{2}{|c|}{$\begin{array}{r}\text { Hjälp med bad/dusch eller } \\
\text { toalettbesök }\end{array}$} \\
\hline & $\begin{array}{c}\text { Äldre med } \\
\text { förgymnasial } \\
\text { utbildning } \\
(\mathrm{n}=886)\end{array}$ & $\begin{array}{c}\text { Äldre med } \\
\text { lägst gymnasial } \\
\text { utbildning } \\
(\mathrm{n}=399)\end{array}$ & $\begin{array}{c}\text { Äldre med } \\
\text { förgymnasial } \\
\text { utbildning } \\
(\mathrm{n}=885)\end{array}$ & $\begin{array}{c}\text { Äldre med } \\
\text { lägst gymnasial } \\
\text { utbildning } \\
(\mathrm{n}=400)\end{array}$ \\
\hline Make/maka & 28 & 28 & 27 & 30 \\
\hline $\begin{array}{l}\text { Annan anhörig/vän utanför } \\
\text { hushållet }\end{array}$ & 13 & 10 & 9 & 9 \\
\hline Kommun/landsting & 52 & 46 & 56 & 47 \\
\hline Hemtjänst på entreprenad & 1 & 6 & 1 & 5 \\
\hline Privat köpt/annan hjälp & 2 & 6 & 1 & 4 \\
\hline
\end{tabular}

Källa: Egna analyser av Socialstyrelsens intervjuundersökning bland hemmaboende äldre 2000. ${ }^{10}$

10 Kolumnerna summerar inte till 100. Några personer (som mest 5 procent) har svarat "vet inte", och ett fåtal (som mest 1 procent) har svarat "frivilligorganisation". 
sett utbildningsbakgrund - föredrar att få informell hjälp från en närstående utanför det egna hushållet. Jämfört med de faktiska hjälpmönstren är diskrepansen slående: långt fler äldre - särskilt äldre med lägre utbildning - får än föredrar hjälp av en närstående som de inte bor tillsammans med. Äldreomsorgens informalisering bland äldre med lägre utbildning àterspeglar således inte de äldres egna preferenser.

\section{Sammanfattning och diskussion}

I alla samhällen och alla tider finns det människor som är beroende av andras hjälp i sin vardag. Omsorg är ett nödvändigt arbete som sällan kan lämnas ogjort utan att människor far illa. Däremot varierar formerna för omsorgsarbetet påtagligt över tid och mellan länder - mellan avlönat och oavlönat arbete, och mellan familj, stat, marknad och frivilliga organisationer. Denna "essentiella plasticitet« i omsorgen (Anttonen et al. 2003 s. 194) har här belysts med fokus på förändringar under de senaste decennierna när det gäller omsorg om funktionshindrade och äldre människor i Sverige. Det har blivit uppenbart att den studerade tidsperioden har varit turbulent när det gäller offentliga resurser och täckningsgrad inom omsorgstjänster för yngre och äldre människor, liksom att statens, marknadens och familjens roller skiljer sig och har förändrats på olika sätt i de båda grupperna. Att inte särskilja äldreomsorg och handikappomsorg - så som tidigare varit vanligt i statistik och forskning - är därför tämligen missvisande.
Sammanfattningsvis:

- Resurserna för de äldres omsorgstjänster har minskat i relation till ökningen av antalet äldre, medan resurserna för de yngres omsorgstjänster har ökat påtagligt - framför allt insatser för de yngre med mest omfattande funktionshinder, och alldeles särskilt personlig assistans.

- Omsorgstjänsternas täckningsgrad har minskat bland äldre (framför allt under 1990-talet) och ökat bland yngre (troligen framför allt under 2000-talet).

- Personalens arbetsvillkor skiljer sig påtagligt när det gäller arbetsbelastning och bedömningen av möjligheten att ge god omsorg.

- Privata utförare av de offentligt finansierade omsorgstjänsterna har ökat sedan 1990-talets början, och är idag betydligt mer omfattande inom handikappomsorgen än inom äldreomsorgen. Inom båda verksamheterna (särskilt inom äldreomsorgen) domineras den icke-offentliga driften av vinstsyftande företag.

- Närstående - familjemedlemmar, släktingar, vänner och grannar - är de vanligaste omsorgsgivarna bland både yngre och äldre som bor hemma och behöver hjälp i sin vardag; alldeles särskilt bland de yngre.

- Gränsen mellan formell och informell omsorg har förändrats sedan slutet av 1980-talet. Bland de äldre finns en trend mot informalisering av omsorgen: hemtjänstens insatser har minskat medan vuxna barn och andra närstående utanför den äldres hushåll har ökat sina insatser - framför allt bland lågutbildade äldre. Närstående till lågutbildade äldre har fått ett ökat omsorgsansvar,

Marta Szebehely \& Gun-Britt Trydegård: Omsorgstjänster för äldre och funktionshindrade... 
både som ersättning till utebliven hemtjänst och som komplettering till hemtjänstens insatser för dem med större omsorgsbehov.

- Bland de yngre finns det både en trend mot informalisering bland dem med mindre hjälpbehov (fler får enbart informell hjälp, framför allt av makar och andra hushållsmedlemmar), och en trend mot formalisering bland dem med stora behov (färre får enbart informell hjälp). Närstående till personer med mindre omfattande hjälpbehov står mer ensamma i sitt omsorgsansvar idag än vid slutet av 1980-talet, medan det motsatta gäller närstående till personer med omfattande hjälpbehov

- Uppgifter om yngre funktionshindrades omsorgspreferenser saknas, men bland äldre är det betydligt fler som får än som föredrar närståendes hjälp - särskilt bland lågutbildade äldre.

- Privat köpt hjälphar en begränsad betydelse för såväl yngre som äldre, men är idag klart vanligare bland äldre med högre än med lägre utbildning. Under 1990-talet ökade andelen äldre som köpte privat hjälp, men denna tendens till marknadisering av äldreomsorgen har avstannat under 2000-talet.

Hur dessa förändringar av resurser, täckningsgrad och gränsomdragningar mellan kommunens, familjens och marknadens insatser hänger samman är en komplex fråga som vi här endast kan beröra kortfattat och tentativt. När det gäller resurser och täckningsgrad är det dock inte alltför spekulativt att relatera de skilda trenderna till den särskilda lagstiftning för vissa grup- per av funktionshindrade (LSS/LASS) som trädde i kraft 1994. Den ambitionshöjning som handikappreformen innebar har gett ett avtryck i form av mer resurser och mer insatser för personer med funktionshinder. Samtidigt har det skett en förskjutning mellan resurser för äldres och yngres omsorgstjänster: av de totala resurserna för äldre- och handikappomsorgen går en minskande andel till de äldre. Eller annorlunda uttryckt, de sammantagna resurserna har inte hållit jämna steg med både de ökade behoven på äldreområdet och de ökade ambitionerna på funktionshindersområdet.

Att personalens villkor på vissa punkter framstår som bättre inom handikappområdet än inom äldreomsorgsområdet är också rimligt att relatera till resursutvecklingen inom de bägge verksamhetsfälten, liksom sannolikt även till organisatoriska traditioner. Men också här spelar lagstiftningen in: ambitionen i LSS att insatserna ska bidra till "goda levnadsvillkor «jämfört med formuleringarna i SoL om "skälig levnadsnivåu har sannolikt betydelse inte minst för personalens bedömning av möjligheten att möta hjälptagarnas behov. God omsorgskvalitet är viktigt inte bara för den som är beroende av hjälpen; att kunna ge omsorg som man själv anser rimlig är också en central arbetsmiljöfråga $\mathrm{i}$ omsorgsarbete. Att så många inom äldreomsorgen anser att möjligheten att ge god omsorg har minskat är därför viktigt att uppmärksamma.

Marknadens roll inom både äldreoch handikappomsorgen har ökat. Det är främst privata utförare av de offentligt finansierade omsorgstjänsterna som har ökat, snarare än privat finansierad hjälp, köpt på en vit eller svart omsorgsmarknad. 
Fortfarande är lite känt om konsekvenserna för hjälptagare och för anställda av att mer omsorgsarbete utförs i privat regi. Frågan är ideologiskt laddad, och diskussionen präglas mer av förhoppningar respektive farhågor än av empiriskt grundad kunskap. Här behövs bättre statistiska underlag om förekomsten av vinstsyftande och icke-vinstsyftande utförare inom den offentligt finansierade omsorgen, men också mer forskning om hur äldre och funktionshindrade, personal och närstående ser på omsorgstjänster i olika regiformer. Den ändring av kommunallagen 1991 som gjorde det möjligt för kommunerna att lämna över utförandet av omsorgstjänster till privata företag är fortfarande inte utvärderad.

De skilda gränsomdragningarna mellan formell och informell omsorg bland hemmaboende yngre och äldre personer är rimliga att relatera till såväl lagstiftning som resursförändringar. Bland de yngre har troligen de ökade resurserna inom handikappomsorgen, särskilt satsningen på personliga assistenter, gjort det möjligt också för personer med mycket omfattande funktionshinder att bo hemma utan vara (helt) beroende av anhörigas hjälp. Den kraftfulla utbyggnad av omsorgstiänster som assistansreformen innebär har inneburit en välfärdsvinst för såväl de funktionshindrade själva som för deras anhöriga. Funktionshindrade med mindre omfattande behov har dock inte fått del av motsvarande välfärdsutbyggnad, och deras anhöriga står i ökad utsträckning ensamma om sitt omsorgsansvar.

Bland de äldre kan inte omsorgens informalisering härledas till ändrad lagstiftning eller till någon uttalad policyförändring. Inte heller finns det några tecken på att för- skjutningen skulle vara en följd av förändrade preferenser bland de äldre, eller att de lågutbildade som är mest berörda av anhörigomsorgens ökning skulle vara mer positiva till anhörigomsorg än äldre med högre utbildning. Sammantaget är det svårt att tolka äldreomsorgens förskjutning i riktning mot mer informell omsorg som annat än en påtvingad informalisering.

Från tidigare studier vet vi att omsorg till äldre från närstående utanför det egna hushållet i stor utsträckning rör sig om medelålders döttrars insatser (Jeppsson Grassman 2003, Szebehely 2005). Döttrars insatser har också ökat mycket mer än söners (Johansson et al. 2003). Det finns således inte bara ett klass- utan också ett könsmönster i den gränsomdragning av äldreomsorgen som vi här har konstaterat: på anhörigsidan är det med största sannolikhet kvinnliga anhöriga till lågutbildade äldre som är mest berörda av äldreomsorgens informalisering.

När det gäller konsekvenserna för anhöriga som vårdar är kunskapsläget begränsat, men vi vet att åtminstone 43000 kvinnor och 15000 män står helt utanför arbetsmarknaden eller har minskat sin arbetstid som en följd av att de ger omfattande omsorg till närstående (Szebehely 2006b s. 457). ${ }^{11}$ I övrigt är mycket litet känt om vad det innebär för försörjning och relation till arbetsmarknaden att vara nära anhörig till en person med omsorgsbehov i Sverige. I internationell forskning betonas att även

11 Uppgiften gäller endast personer 55 år och äldre, och innebär därför en underskattning av det totala antalet i befolkningen vars förvärvsarbete påverkats av att vårda en närstående.

Marta Szebehely \& Gun-Britt Trydegård: Omsorgstjänster för äldre och funktionshindrade... 
om de flesta upplever sitt omsorgsansvar som meningsfullt och givande så har omsorgen ofta ett pris för den som vårdar. Många får försämrad ekonomisk situation på kort och lång sikt som en följd av att de minskar sin arbetstid eller avstår helt från förvärvsarbete; andra upplever ökad tidspress, trötthet och andra negativa hälsoeffekter av kombinationen förvärvsarbete och omfattande omsorg (se t.ex. Phillips et al. 2002, Pickard 2004).

I ett jämförande välfärdsstatsperspektiv har de nordiska ländernas väl utbyggda och väl fungerande omsorgstjänster betraktats som viktiga välfärdsresurser både för de äldre eller funktionshindrade personer som får del av tjänsterna och för deras närstående. Jämfört med länder med mindre omfattande offentligt finansierade omsorgstjänster har hjälpbehövande personer i Norden varit mindre beroende av andra familjemedlemmar för omsorg, och deras (kvinnliga) anhöriga har haft större möjligheter att förvärvsarbeta trots omsorgsbehövande familjemedlemmar. Begreppet de-familialisation (McLaughlin \& Glendin- ning 1994, Esping-Andersen 1999, Leitner 2003) har använts i litteraturen för att beteckna att individer i olika livssituationer på detta sätt blivit mindre beroende av sina familjerelationer för sin välfärd, och de nordiska välfärdsstaterna framstår i jämförande studier som mer'de-familiserande' än andra länders välfärdssystem.

Såvitt vi har kunnat finna har ingen komparativ välfärdsforskning granskat socialpolitiska reformer separat för äldre och för funktionshindrade. Vår analys i denna artikel tyder på att den svenska handikappomsorgen har utvecklats i riktning mot minskat familjeberoende och ökad autonomi för både funktionshindrade personer och deras anhöriga. De välfärdspolitiskasärdrag som omvärlden uppfattar som typiskt nordiska har således förstärkts - åtminstone för funktionshindrade med de mest omfattande hjälpbehoven. På äldreomsorgsområdet finns en motsatt trend: den informalisering med klassförtecken av de äldres omsorg som vi har konstaterat väcker frågan om den svenska äldreomsorgen är på väg bort från den nordiska välfärdsmodellen.

\section{Referenser}

Ahnlund, P. \& Johansson, S. (2006) „Omvårdnadsutbildning som mål eller medel? Om legitimitetsproblem och kunskapssyn", Socialvetenskaplig Tidskrift, 13(3), s. 212-227.

Anttonen A., Baldock J. \& Sipilä J. (eds.) (2003) The young, the old and the state: social care systems in five industrial nations. Cheltenham: Edward Elgar.

Arbetsmiljöverket (2002) Personliga assistenters arbetsmiljö. Ett riksövergripande projekt. 2002:5.
Barron K., Michailakis D. \& Söder M. (2000) „Funktionshindrade och den offentliga hjälpapparaten«. I M. Szebehely (red.) Välfärd, vård och omsorg. SOU 2000:38. Kommittén Välfärdsbokslut. Stockholm: Fritzes.

Batljan, I. \& Lagergren, M. (2000) Kommer det att finnas en hjälpande hand? LU 1999/2000, bilaga 8. Långtidsutredningen. Stockholm: Finansdepartementet.

Bäckman, O. (2001) „Med välfärdsstaten som 
arbetsgivare. Arbetsmiljön och dess konsekvenser inom välfärdstjänsteområdet på 1990talet». I M. Szebehely (red.) Välfärdstjänster $i$ omvandling. SOU 2001:52. Kommittén Välfärdsbokslut. Stockholm: Fritzes.

Daly, M. (2002) "Care as a Good for Social Policy», Journal of Social Policy, 31 (2), pp. 251-270.

Daly, M. \& Lewis, J, (2000) »The concept of social care and the analysis of contemporary welfare states", British Journal of Sociology, 51 (2), pp. 281-298.

Esping-Andersen, G. (1999) Social Foundations of Postindustrial Economies. NewYork: Oxford University Press.

Fine, M. \& Glendinning, C. (2005) »Dependence, independence or inter-dependence? Revisiting the concepts of 'care' and 'dependency'", Ageing \& Society, 25, pp. 601-621.

Forssell, E. (2004) "Utsatt, privilegierad - en studie om att återfå assistansersättning efter 65«. I RFV analyserar 2004:10. Assistansersättning efter 65 - utvärdering av de nya reglerna. Stockholm: Riksförsäkringsverket.

Fried, R. (2007) Hemtjänsten i Stockholm - en enkät till brukarna hösten 2006. Stockholm: Utrednings- och statistikkontoret.

Försäkringskassan (2005) Assistansersättning 2000-2004. Statistik 2005:7.

Försäkringskassan (2006) Socialförsäkringsårsboken 2006.

Gustafsson, RÅ. \& Szebehely, M. (2005) Arbetsvillkor och styrning $i$ äldreomsorgens hierarki - en enkätstudie bland personal och politiker. Stockholms universitet: Institutionen för socialt arbete.

Gustafsson, RÅ. \& Szebehely, M. (2007) „Privat och offentlig äldreomsorg - svenska omsorgsarbetares syn på arbetsmiljö och politisk styrning", Socialvetenskaplig Tidskrift, 14 (1), s. 47-66.

Hammarström, G. (2002) "'Hemtjänsten behöver mera hjälp' - Äldre hjälpmottagares erfarenheter av hemtjänsten", Socialmedicinsk Tidskrift, nr 3, s. 271-284.

Hjalmarson, I. (2003) Valfrihet i äldreomsorgen-en reform som söker sin form. En utvärdering av kundvalsmodellen iStockholms stad. Stockholm: Stiftelsen Stockholms läns Äldrecentrum.

Hugemark, A. \& Wahlström, K. (2002) Personlig assistans i olika former. Mål, resurser och organisatoriska gränser. FoU-enheten, Stockholms socialtjänstavdelning, Stockholms stad.

Hugemark, A. (2006) „Åter i stöpsleven: Personlig assistans mellan marknad och reglering", Socialvetenskaplig Tidskrift, 13(4), s. 313-330.

Højlund, H. (2005) „At give de ældre røst-Tre brugerorienterede tilgange til udviklingen i ældresektoren". I M. Szebehely (red.) Äldreomsorgsforskning $i$ Norden. En kunskapsöversikt. Köpenhamn: Nordiska ministerrådet.

Jacobson, A. (2000) „Från vanmakt till makt». I P. Brusén \& L-C. Hydén (red.) Ett liv som andra. Lund: Studentlitteratur.

Jeppsson Grassman, E. (red) (2003) Anhörig skapets uttrycksformer. Lund: Studentlitteratur.

Johansson L., Sundström G. \& Hassing L. (2003) "State provision down, offspring's up: the reversed substitution of old-age care in Sweden", Ageing\& Society, 23 (3), pp. 269-280.

Jönson, H. \& Taghizadeh, A. (2006) „Ideologibaserade livsloppskonstruktioner inom handikappoch äldrepolitik", Socionomens Forskningssupplement, nr 19, s. 18-31.

Larsson, K. (2006) „Hemtjänst och anhörigvård». I Äldres levnadsförhaillanden. Arbete, ekonomi, hälsa och sociala nätverk 1980-2003. Stockholm: Statistiska centralbyrån.

Larsson, M. (2004) »Personlig assistent - kompis, startmotor eller någons armar och ben?». I K. Gynnerstedt (red.) Personlig assistans och medborgarskap. Lund: Studentlitteratur.

Leitner, S. (2003) "Varieties of familialism. The caring function of the family in comparative perspective», European Societies, 5 (4), pp. 353-375.

McLaughlin, E. \& Glendinning, C. (1994) "Paying for care in Europe: Is there a feminist approach?». I L. Hantrais \& S. Mangen (red.) Concepts and contexts in international comparisons. Loughborough: Centre for European Studies.

Marta Szebehely \& Gun-Britt Trydegård: Omsorgstjänster för äldre och funktionshindrade... 
Pfau-Effinger, B. (2005) "Welfare state policies and the development of care arrangements", European Societies, 7 (2), pp. 321-347.

Phillips J., Bernard M. \& Chittenden M. (2002) Juggling work and care. The experiences of working carers of older adults. Bristol: The Policy Press \& Joseph Rowntree Foundation.

Pickard,L. (2004) Caring for older people and employment. A review of the literature prepared for the Audit Commission. London: Audit Commission.

RFV (2001) Socialförsäkringsårsboken 2001. Stockholm: Riksförsäkringsverket.

Riksrevisionsverket (2004) Personlig assistans till funktionshindrade, RiR 2004:7. Stockholm.

SCB (2006) Skola vaird och omsorg i privat regi - en sammanställning av statistik 1995 - 2005. Ekonomisk statistik 2006:5. Stockholm: Statistiska centralbyrån.

Selander, V. (2003) "'Mitt liv i dina händer'. En studie om hur en grupp personer med funktionshinder bemästrar behovsbedömningssituationen «. Magisteruppsats. Stockholm universitet: Institutionen för socialt arbete.

Sipilä, J. (red.) (1997) Social Care Services: The Key to the Scandinavian Welfare Model. Aldershot: Avebury.

Socialstyrelsen (1997) Levnadsförhållanden för personer med omfattande funktionshinder.

Socialstyrelsen (2000) Bo hemma på äldre da'r.

Socialstyrelsen (2004a) Konkurrensutsättning och entreprenader inom äldreomsorgen. Utvecklingsläget 2003.

Socialstyrelsen (2004b) Konkurrensutsättning inom äldreomsorgen. Lägesrapport.

Socialstyrelsen (2006) Brukare och anhöriga om kvalitet $i$ äldreomsorgen. Kvalitetsbarometern 1998, 1999, 2002, 2004 och 2005.

Socialstyrelsen (2007a) Handikappomsorg. Lägesrapport 2006.

Socialstyrelsen (2007b) Funktionshindrade personer år 2006. Kommunala insatser enligt socialtjänstlagen samt hälso- och sjukvårdslagen.

Socialstyrelsen (2007c) Vård och omsorg om äldre - Lägesrapport 2006.

Socialstyrelsen (2007d) Äldre - vaird och omsorg 2006.
Socialstyrelsen (2007e) Kostnader för assistansersättning (LASS). Analys av utvecklingen 19942005.

Socialstyrelsen (2007f) Lika olika socialtjänst? Kommunala skillnader i prioritering, kostnader och verksamhet.

SOU 2001:79 Välfärdsbokslut för 1980-talet. Kommittén Välfärdsbokslut. Stockholm: Fritzes.

SOU 2004:68 Sammanhaillen hemvaird. Äldrevårdsutredningen. Stockholm: Fritzes.

SOU 2005:100 På den assistansberättigades uppdrag. Assistanskommittén. Stockholm: Fritzes.

SOU 2007:37 Vård med omsorg - möjligheter och hinder. Delegationen för mångfald inom vård och omsorg. Stockholm: Fritzes

Szebehely, M. (2005) "Anhörigas betalda och obetalda äldreomsorgsinsatser». I Forskarrapporter till Jämställdhetspolitiska utredningen. SOU 2005:66. Stockholm: Fritzes.

Szebehely, M. (2006a) „Omsorgsvardag under skiftande organisatoriska villkor - en jämförande studie av den nordiska hemtjänsten", Tidskrift for Arbejdsliv, 2006, 8(1), s. 49-66.

Szebehely, M. (2006b) »Informella hjälpgivare». I Äldres levnadsförhållanden. Arbete, ekonomi, hälsa och sociala nätverk 1980-2003. Stockholm: Statistiska centralbyrån.

Szebehely M., Fritzell J. \& Lundberg O. (2001) Funktionshinder och välfärd. SOU 2001:56. Kommittén Välfärdsbokslut. Stockholm: Fritzes.

Tegsjö B., Hedin G. \& Eklund I. (2000) Kartläggning av magra organisationer. Stockholm: Rådet för arbetslivsforskning.

Thorslund M., Lennartsson C., Parker MG. \& Lundberg O. (2004) "De allra äldstas hälsa har blivit sämre", Läkartidningen, 101 (17), s.1494-1499.

Trydegård, G-B. (2001) „Välfärdstjänster till salu privatisering och alternativa driftformer under 1990-talet«. I M. Szebehely (red.) Välfärdstjänster $i$ omvandling. SOU 2001:52. Kommittén Välfärdsbokslut. Stockholm: Fritzes.

Trydegård, G-B. (2005) „Äldreomsorgspersonalens arbetsvillkor i Norden - en forskningsöversikt». I M. Szebehely (red.) Äldreomsorgsforskning 
i Norden. En kunskapsöversikt. Köpenhamn: Nordiska ministerrådet.

Åström, C. (2000) „Förändringar och förskjutningar i välfärdens rättsliga reglering under 1990-talet«. I M. Szebehely (red.) Välfärd, vård och omsorg. SOU 2000:38. Kommittén Välfärdsbokslut. Stockholm: Fritzes.

\section{Summary}

\section{Care services for elderly and disabled persons: different conditions, different trends?}

Care services for disabled and elderly persons are essential parts of the Nordic welfare states. While these services are often not separated in statistics and research, a comparison of the two services reveals substantial differences in the case of Sweden. This article focuses the recent developments of Swedish elder care and disability care; the changing roles of the state, the family and the market; and the consequences of the changes for all parties concerned: the elderly and disabled persons, their next of kin and the care staff.

The analysis shows that the financial resources for elder care have declined in relation to the increasing number of old people, while the resources for disability care have increased substantially. The coverage of services has decreased among elderly people and increased among the younger. The care workers in elder care and disability care report very different working conditions regarding their workload and the possibility to meet the needs of the care recipients.

Private providers (mainly for-profit companies) of publicly financed care services have enlarged their share in both services, but are far more common in disability care than in elder care. The boundary line between formal and informal care has changed in both groups, but partly in opposite directions. There is a trend of informalisation among elderly people with larger as well as smaller care needs, especially among elderly with lower education. Among less disabled younger persons there is a similar trend of informalisation, while there is an opposite trend towards more formal care services among disabled persons with large needs of assistance and support.

In relation to the Nordic welfare state model, care services for elderly and for disabled people in Sweden seem to be moving in different directions. An increasing number of disabled people with extensive care needs can lead their lives with greater autonomy and less family dependency than previously. Among frail elderly people, decreasing public support and increasing, often coerced, family dependency, might instead be a sign of a departure from the Nordic model. 